Property Management, 2010, Volume 28, Issue 5,

Pages 320 - 338

This article is (c) Emerald Group Publishing and permission has been granted

for this version to appear here (http://dspace.mah.se/).

Emerald does not grant permission for this article to be further

copied/distributed or hosted elsewhere without the express permission from

Emerald Group Publishing Limited.

www.emeraldinsight.com

\title{
Local housing administration models for large housing estates
}

\author{
Gunnar Blomé \\ Department of Urban Studies, Malmö University, Malmö, Sweden
}

\begin{abstract}
Purpose - The purpose of this paper is to describe and evaluate three different models of how to organise services to tenants in municipal housing companies.

Design/methodology/approach - The empirical data used in this study are gathered from a detailed two-year case study.

Findings - Three different functions are identified: customer service (e.g. reporting of faults); the letting process; and caretaking (day-to-day activities and control over in- and outdoor areas). The three models for local administration differ as to which functions are decentralised to a local group and which are centralised, and are evaluated from several different perspectives. The models where more decisions are decentralised leads to better information about the local conditions, makes it easier to coordinate work in an area, creates more motivation for the staff and makes it easier to involve the tenants. The main problem with the decentralised models is moral hazard problems, e.g. that the local team create their own agenda, are pressured by certain tenants to give them advantages and that the result is lack of control and an inconsistent policy in the company.

Research limitation/implications - The primary issue of the study is how housing companies can organise their resources in order to create an efficient local administration in large housing estates. Further research is needed to decide if the economic profitability differs between different organizational models in relation to tenants' perceived service quality.

Originality/value - The research identifies and analyses different organisation models for local administration in large housing estates more thoroughly than earlier research.
\end{abstract}

Keywords - Residential property, Modelling, Customer service management, Local housing authorities, Sweden 


\section{Introduction}

\subsection{General background}

Municipal housing companies own around 885,000 rental apartments in Sweden, and this represents 22 percent of the total housing stock in Sweden (Statistics Sweden, 2009). These companies are not traditional social housing companies, but focus on a broad group of households. In the last 15 years the companies have become more "businesslike" and professional (see Borg and Lind, 2007). The rents are negotiated every year by the local municipal housing company and the local tenants association and these rents set the level for similar dwellings in private landlord estates. In the beginning of 1990s the Swedish government removed all subsidies and the reduction of taxes for municipal housing companies, so they are competing on equal terms with the private sector. But the fundamental objectives, creating social values by providing better housing conditions at affordable costs to all kind of social groups is still unchanged (Andersson et al. , 2003, 2005; Öresjö et al. , 2004). There are many large housing estates in Sweden. These areas are often managed by municipal housing companies and most were built during the so called "Million dwelling programme". This program's aim was to increase the housing stock by one million units in a period of ten years from 1965-1974. Around 950,000 houses were produced, 600,000 of these were dwellings in large housing estates, mostly owned by municipal housing companies (Ramberg, 2000). Similar kinds of building projects were carried out in several countries in Western Europe, using modernised building methods (Turkington, 1995, Van Kempen et al., 2006).

Municipal housing companies have to become more cost efficient and more focused on the tenants' requirements, because of reduced subsidies and increased competition. They have to combine social goals with business goals. Increased segregation on the housing market as a whole, and also within the municipal housing stock, creates new problems that the company needs to handle. In addition to this, the immigration situation in Sweden has changed over the last 20 years from work- to refugee immigration. Besides increased unemployment and revisions of the Swedish welfare system back in the 1990s, this has aggravated the socio economic segregation, particularly in large housing estates. The housing companies are trying hard to find efficient methods to deal with this situation (Andersson et al., 2003, 2005; Öresjö et al., 2004; Borg and Lind, 2007).

\subsection{Research problem}

Since the last part of the 1980s the municipal housing companies in Sweden have focused more on improving local services and the local administration (Liedholm, 1991, Lindberg, 1994a; Öresjö, 1996; Johansson, 1998; Högberg and Högberg, 2000; Blomè, 2006). Studies show how important the processes of maintenance delivery are for interaction with tenants and for the opportunity to create an effective management (Van Mosel, 2008). The housing company's organization becomes a tool to achieve this, but there are many different ways to organise resources.

A number of models have been tested, but there has been very little research on the structure and role of the local administration in the municipal housing companies. How can they organise their resources in order to create an efficient local management? The main purposes of the article are:

- to identify a number of different local administrative models; and

- to evaluate how these models have worked in Sweden using a number of case-studies.

From a practical perspective this study gives a deeper knowledge of potential advantages and disadvantages of different models for organizing service provision in large housing estates. From the perspective of the scientific community, the study introduces three models of organizing local housing administration. It also identifies the specific elements of local housing administration. The detailed presentation of these new organisation models and experiences give a basis for future international comparisons.

\subsection{Research methodology}

The empirical data used in this study is a detailed two year case study of organisational changes in Malmö's municipal housing company (MKB), and an interview study in four other municipal housing 
companies in Sweden. The research study began as an evaluation of MKB's organizational model but was expanded to include other housing companies in order to increase the knowledge about various organizational options. The study's theoretical framework is based on both research into public housing and service management. According to Gummesson (2004) a case study approach is suitable when a phenomenon is complex or knowledge is missing. This research field of how housing companies organise their resources in order to create an efficient local management scheme is not well researched. For that reason a case study approach could be useful.

The case study was done with the help of participatory observations and interviews with frontline staff and management. A questionnaire survey was also done at the end of the study to test frontline staffs' opinion about organizational changes. The questionnaire was delivered to 107 respondents with a reply frequency of 76 (71 per cent). The information went through several steps of analysis using spreadsheets.

The direct observations were used to follow the internal work by participating in small meetings and conferences. This method helped inform the research about the housing company's development work, provided information about management decision-making and frontline staffs' way of handling various problems. The observations were ranging from two hours discussion with groups of staff to passively following events during ordinary days. The interviews were done individually or in small groups depending on circumstances and staff availability. The employees were asked about their working roles, how everyday tasks were handled, tenant relations and cooperation among local management staff and other parts of the company including external staff. The interviews lasted between one and three hours depending on staff work situation and participants' responses.

The interview study in the four other municipal housing companies included group- as well as individual interviews with key personnel in the company management and the frontline staff. The survey was conducted in the southern part of Sweden and the empirical findings from the case study in MKB served as a starting point identifying central interview questions and organizational functions to ask about. The interviews took anything from one to two hours depending again on the staff's work situation and participants' responses. This study was done to understand alternative way of organizing resources and to identify possible problems in the different models.

The various housing companies' organization was categorised in relation to the three general organizational models described in section 3 .

The section about model 3 below is more extensive than the others because more empirical information was gathered about this model (Table). The reason for this was that the research project started as an evaluation of this model and subsequently expanded to include more models to increase knowledge of various organizational alternatives.

\begin{tabular}{lccc}
\hline Case study & 2004 & 2005 & 2006 \\
\hline Interviews & 6 & 6 & 4 \\
Frontline staff & 4 & 2 & 2 \\
Management & 2 & 4 & 2 \\
Observations & 5 & 5 & $76 / 107^{\mathrm{a}}$ \\
Questionnaire & & & \\
Other companies & & 3 & 9 \\
Interviews & 2 & 5 \\
Frontline staff & 1 & 5 \\
Management & & &
\end{tabular}

Notes: ${ }^{a}$ More detailed results from the questionnaire is presented in Blomè (2006)

Table I. Empirical methods used 


\subsection{Structure of article}

The paper is divided into five sections. In the next section the historic trends in housing management are described. Section 3 presents central concepts and definitions. Section 4 presents results from the case study and the supplementary study. Section 5 contains the analysis. Conclusion and recommendations can be found in the final section.

\section{Historic trends in housing management}

Management trends in rental housing in Sweden are presented in this section and related to some more general theories about organization and administration. In the beginning of the 1930s the Swedish rental market was dominated by small private housing companies with a small number of properties. Larger estates often had a local porter or janitor living on the premises and taking care of the day-to-day operational local administration. In the period from the beginning of 1940 s to the end of 1970s, a generally used organisation model was a hierarchic specialised functional model. A source of inspiration was the successful industrial production (Mintzberg, 1979; Lindberg, 1994a; Lindberg, 1994b). This seemed to be a natural solution for managing large scale housing units. After this period the focus changed; from production of houses to maintenance and production of services. The earlier type of specialization resulted in inefficiency and bad staff motivation (Lindberg, 1994a).

Tenant movements in the late 1970s and in the beginning of the 1980s changed the housing companies' strategy, towards giving the tenant more options and increased participation in the management of the estate (Lennartsson et al., 1992). One example was the introduction of tenantdirected maintenance. This resulted in new ways of organizing administration locally (Lindberg, 1994a; Johansson, 1992, 1994, 1998). The Swedish housing association of municipal housing companies (SABO) started a development work in the beginning of 1980s. This work was finished and published in 1982, giving housing companies recommendations of how to organise their administration. The basic aim was improved relations between staff and tenants, through a geographically divided administration, with locally based offices. Experience showed that giving the local staff more responsibility created an opportunity for mutual understanding between local staff and the tenants, which was seen as a basic condition for increased tenant participation. This was later seen as the starting point for the housing companies to improve their management. Housing management has during this time gone from a rather strict technical focus to more of a focus on personal relations with tenants and to issues relating to the social environment.

Johansson (1998) and Franklin (2000) underline the democratic aspects describing positive examples of giving frontline staff more responsibility and more influence on strategic decisions. One obvious advantage was that staff motivation significantly went up. A positive side-effect of this was that the number of sick listed employees went down. Robinsson (2006) mentioned the importance of adapting to the specific context of the estate, e.g. social, economic and cultural differences between estates. There are several research reports that consider a decentralised local management to be a winning concept, in particular for changing socially weak neighbourhoods and achieving tenant participation (Walker, 2001; Flint, 2002; Brattbakk and Hansen, 2004; Lindberg and Liedholm, 1998). Research indicates that tenant participation gives improved housing quality, increased knowledge for both tenants and the company, higher efficiency, fewer conflicts and less disappointed tenants (Owen, 2002; Hickman and Reid, 2002; Flint, 2002).

Power and Tunstall (1995) believe that improved services, locally-improved maintenance and administration can replace or at least reduce the need for large scale investments. In their research they studied 20 unpopular estates in Great Britain over a period of 15 years. Their model of organizing housing administration locally is still of current interest, and even today is a commonly used model in Sweden.

From the early 1990s, new ways of organizing administration have appeared. One pioneering trend in Sweden that also is taking place in other European countries is the increased use of outsourcing as a solution to the need for increase efficiency (see, e.g. Lindberg, 1994a, Sirmans et al., 1999; Saugeres and Chapman, 1999; Becker et al. ,2001). One highlighted problem in different countries is 
that the legal system for procurement leads to contractors being chosen mainly on price with little regard to service issues and quality. This can obviously have a negative impact for developing relations with tenants and in particularly within socially deprived areas.

Technical developments were leading housing companies into a new phase with demand for skilled employees with practical experience. One example is that housing management information today to a great extend is computer-based and web-based compared to earlier times. This means that practical knowledge alone no longer is sufficient (Lindberg, 1994a; Deakin, 1998). This development is also a result of an even more decentralised housing management and increased responsibilities for staff with tenant contacts.

It should also be mentioned that self-management, which means that tenants are involved in the care of open space management and taking over various maintenance tasks, have been tested in local housing management since the beginning of 1990s. However, this model has not become widespread, even though this form of housing management according to earlier research has improved the social environment and enhanced tenants' participation and sometimes has contributed to revitalising declining urban areas (see Cars et al., 1996; Ericsson, 2002; Bengtsson et al., 2003; Lindgren and Castell, 2008). Two possible explanations why self-management has not become a common practice management solution are difficulties in finding tenant and employees enthusiasts, and that it is not a prioritised management issue (Lindgren and Castell, 2008).

Housing management trends have naturally followed the development of the surrounding society, and the need to give a higher focus to economic issues as subsidies have decreased since the early 1990s (see Borg and Lind, 2007). This has affected all aspects of the companies: More market oriented rents in order to increase revenues in more attractive areas and reducing vacancies in less attractive areas. More focus on technical efficiency and energy savings (see Högberg et al., 2010) and last but not least experiments with new administrative models especially in areas with high operating and maintenance costs as in the large segregated housing estates build during the so called Million Dwellings Program mentioned above where it was very important to adapt the management strategies to the local situation, e.g. in terms of demographic structure. The analysis section returns to these different trends in housing management and the background factors affecting them.

\section{Housing administration models}

There is no generally agreed definition of housing administration. This function is wide ranging, covering aspects of estate and tenancy management, at both a strategic level and day-to-day contacts with individual tenants. This paper is focusing on the local administration, which consists of operational resources that provide services to tenants. Lindberg (1994a) and Högberg and Högberg (2000) define this in general terms and recognised this part of housing administration as the core business. In order to discuss more specific models a more detailed definition is necessary.

Local housing administration can be defined as all the activities where the housing company and tenants meet. These activities can be divided into three parts; customer service, caretaking and letting, as described in the next section.

In a more wide-ranging definition it is necessary to consider supporting activities including ground management and heating, ventilation and sanitation installations. These activities are focusing on technical services and are sometimes outsourced. Other supporting activities that are excluded in this study's definition of local administration are the economic control function and various internal management issues, e.g. personnel management.

\subsection{Elements of housing administration}

In this study three different housing administration services are identified:

(1) Customer service is a function where tenants can contact the housing company to report various faults. This function involves phone calls, email and face-to-face contacts between tenant and staff. The contact can concern general questions, fault reports in and around the apartments, reports about disturbances and other complaints. The main task of customer 
service is to help tenants to get help by guiding, informing and contacting responsible staff/management. It is common that a private security company manages emergency activity at evenings/nights when the housing company's services are closed.

(2) Letting incorporates processes connected with estate agency, writing contract with tenants, inspections, marketing, internal apartment exchanges and tenant selection. An inspection is a process to establish and control conditions of an apartment when a tenant moves out. The purpose of the marketing activity is to make apartments visible for potential tenants. Internal exchange is when tenants are moving within the company's estates. The tenant selection is a basic decision-making process, usually based on internal policy, when the apartment is leased to a new tenant.

(3) Caretaking includes day-to-day activities and control over in- and outdoor areas. It contains tenant consultations, day-to-day care of property, the ordering and coordination of contractors for specialised works, solving problems related to fault reports, solving conflicts between tenants (e.g. after complaints) and the handling of different complains. This activity also includes uncomplicated repairs in apartments, basic property maintenance services and can also include economic responsibility for a local budget. The range of tenants' options is managed in this process and means, e.g. that tenants in certain situations can choose wall painting/paper, floor covering and domestic appliances/other equipments etc.

There are many ways to organise the local housing administration. No useful theoretical model to analyse organizational differences on this detailed level was found, so three new models are presented below. It is these three alternatives that are analysed in the rest of the paper.

\subsection{Organizational models}

The three models presented below differ in how the three functions above are allocated between the local and central level in a housing company:

- Model 1 is an administration model where only Caretaking is carried out at the local level. Customer service is centralised and most contacts concerning, e.g. reporting of faults and complaints go through a central unit in the company. They forward the information to the local caretakers or to external firms to which the service has been outsourced. All the functions related to letting are also centralised, even if some inspections might be carried out by local staff. The central unit chooses tenants and then just informs the local staff (Figure 1).

- Model 2 is an administration model where both customer service and caretaking are carried out at the local level. This means that after a tenant has been selected, all contacts concerning property management goes through the local unit. Letting is however handled centrally in the company (Figure 2).

- Model 3 is an administration model where customer service, caretaking and letting are all managed together at the local level, through a joint local work-team where most work is carried out in-house, even if specialised repairs are outsourced to external firms (Figure 3 ).

\section{Empirical findings concerning the organizational models}

Details of how the models worked in practice are described below and respondents' experiences are then presented, starting with model 1 , followed by model 2 and model 3. 


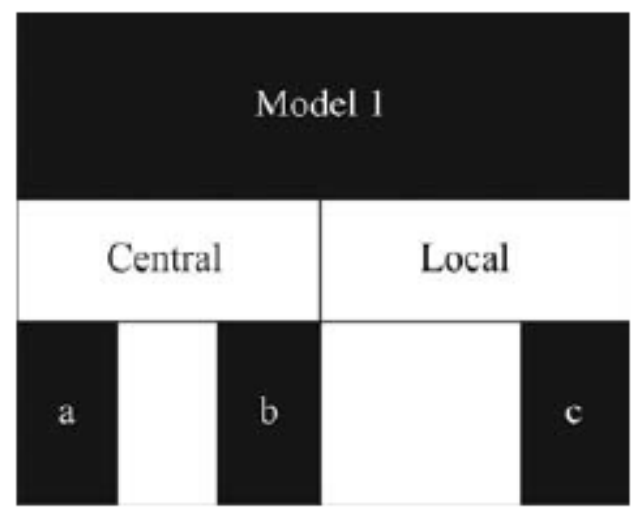

Figure 1.

Only caretaking (c) at the local level

\subsection{Model 1}

4.1.1 How the model worked in practice. Model 1 is a local administration model where only caretaking is carried out at the local level. The middle-sized Company (D) (9,500 tenants and 55 employees) was the only company in this study using this model. The letting process and costumer service were centralised and the caretaking was managed at the local level by external contractors.

Customer service was organised with a call-centre function and the tenants contact staff by using email, phone or by visiting the company headquarter. The call centre registered incoming faults and communicated them to the contractors.

The letting process was centralised and was managed in-house by company staff. Potential tenants apply for new apartments through an internet-based system or by visiting the headquarters. A queue-based system determines the apartment distribution alongside individual economic conditions, credit history and references from other landlords. Company D has no system to follow up why tenants' were leaving and a vacant apartment was usually not shown to potential tenants by the company. Instead it was the current tenant that takes care of this process, showing the apartment to the potential tenants. Managers handle inspections, but it seemed not to be routine in every single transaction, and an apartment's condition was not frequently controlled before the new tenant moved in.

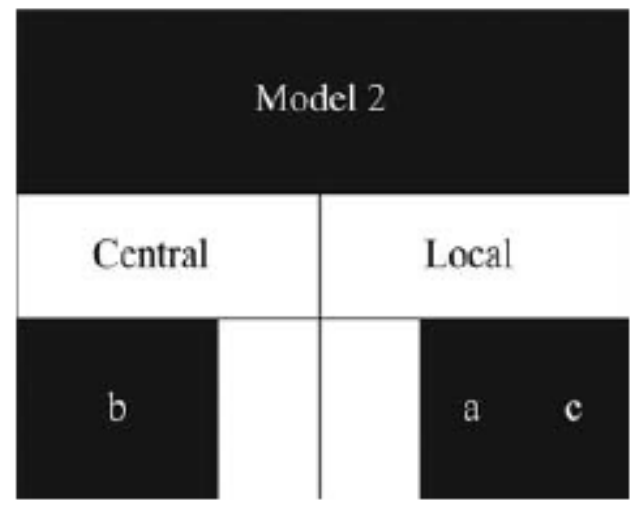

Figure 2.

Costumer service (a) and caretaking

(c) at the local level 


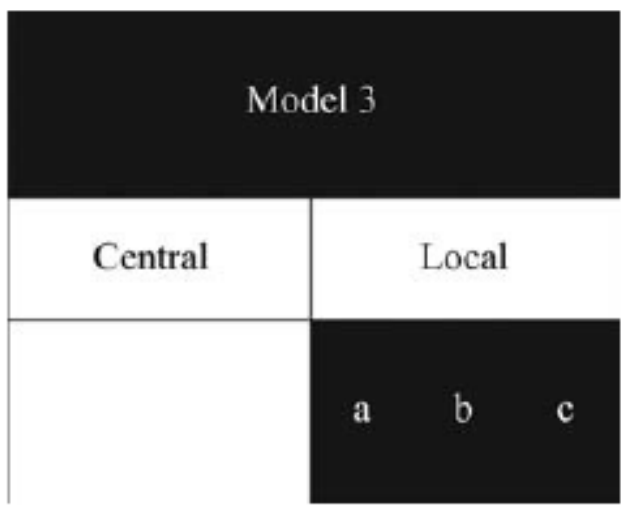

Figure 3.

Costumer service (a), letting (b) and caretaking (c) are all carried out at the local level

The caretaking process contains several elements in model 1 . The first part is when the tenant contacts the customer service to report a fault, and the second part is when operational staff contact the contractor and the last part is when the contractor remedies the faults. In more complicated cases the contractor used specialist companies. In these situations the contractor was completely responsible for the administration and took care of all necessary contacts.

The contractor handled reports about different types of disturbances in the housing area during the day. At other times this was managed by a security company. The contractor used a ledger to document actions and gave weekly reports back to the company. The invoices from the contractor were controlled randomly and tenants' views were collected through a questionnaire once every year. The property manager in Company $D$ operates from the headquarters and had overall economic responsibility for the housing areas and also runs social projects, and cooperates with the municipality, the schools and the police.

4.1.2 Respondents' opinions. The respondents in Company D indicated that it sometimes took a long time to correct faults, from the time a tenant contacts the call-centre to the fault being fixed by the contractor. Company $D$ plans to introduce some kind of time guarantee which means that the fault should be resolved within a fixed time. One obvious problem was information loss from the callcentre to the contractor, as there was no direct contact between the tenant reporting a fault and the person that should fix the problem. "Sometimes it takes more time than necessary because we got the wrong description from the company staff, and have to change our preparations, and call the tenant again to get the full picture" (quoted from a contractor). The respondents also think that the letting process was unclear. "We need to improve tenant contacts with the contractors in the beginning to be able to establish a relation between tenant and caretaker, and to be informed about possible shortcomings. In the end we must correct faults and put pressure on our suppliers" (quoted from a manager). This indicates a lack of control because the company misses a natural opportunity to get information about dwellings and meet new tenants.

Company $\mathrm{D}$ seemed to have a very detailed description of the caretaking process and bookkeeping activities, which simplifies monitoring and evaluation of profitability. "The contractor sends me a detailed diary of operating activities each week" (quoted from a manager). The respondents, however, indicated that a clear description and control of the housing area activities could have a negative impact on contractors' initiative. "Housing areas needs are different and it is difficult to create a model that cover instructions of all activities, especially to get an overall picture of social needs" (quoted from a manager). 


\subsection{Model 2}

4.2.1 How the model worked in practice. Model 2 is a local administration model where customer service and caretaking are decentralised, while letting is centralised. Company $A$ and Company $E$ are two housing companies using this model.

Company E has 2,000 apartments and 25 employees with shared responsibility between local staff who takes care of fault reports and repairs, and central staff who are responsible for social projects and the letting process. A contractor in company $\mathrm{E}$ takes care of cleaning, and the company has a centrally-organised team to take care of the outdoor environment. The use of contractors is often linked to apartment renovations, ongoing property maintenance and more complex time consuming fault reports, while ordinary repairs are made by the in-house caretaking staff.

Company A has 22,500 apartments and 300 employees with a shared responsibility between the joint local work teams that takes care of fault reports, cleaning and outdoor environments and the central staff that runs letting process and social projects.

Customer service is in these cases organised in a way that tenants can contact local authority staff directly by using email, phone or by visiting the local offices. The companies have kept a small central call centre to improve services and help tenants to find their way to the right person in the local organization. If the tenants contact the central call centre, staff simply just pass the request to the appropriate person in the local organization.

The letting process is centrally organised in both companies, and apartments are rented out on the basis of new potential tenants' interest, each company's specific hiring policy and the letting assistant's selection. Centrally-based staff handle all tenant contacts in the letting process, but cooperate with local staff in terms of apartment renovations for a new tenant, etc. Like Company $D$ (model 1 ) there is no system in Company A or Company E to follow up leaving tenants, and vacant apartments are not always shown to potential tenants. Instead it is common that the existing tenant takes care of this process.

Caretaking is organised in three geographical-divided teams in Company E, and Company A has a similar model, organizing the local-level staff in seven different units. Locally-based staff in Company $\mathrm{E}$ works very independently in their housing areas. They are economically responsible and take care of fault reports about different kinds of disturbances. Company A used a joint local work team with full economic responsibility. One person in this local work team has more responsibility than other staff members and makes sure things get done as they should.

4.2.2 Respondents' opinions. Customer service was organised in a way that means that tenants contact the responsible local staff directly. Both companies considered it to be an advantage to have this type of locally organised staff. Company A thinks it is easier to coordinate work, and Company $E$ suggests that it is easier to identify and understand the needs of different tenants and areas when responsibility is decentralised, and when tenant contacts are directly linked to persons in the field. Company $\mathrm{E}$ has however noticed that these direct contacts take much time from the operating staff's other chores. "Occasionally I talk with tenants most of the day and then I have no time to solve faults, deal with invoices and check my neighbourhood" (quoted from frontline staff). It appears that lonely tenants sometime use the staff to satisfy a social need.

The letting process was in both companies organised centrally. Vacant dwellings are advertised over the companies' web sites. Company E mentioned that they do not always have a routine to introduce and show vacant dwellings. One explanation is that it is more difficult to coordinate this activity when staff are separated in two parts and not working from local offices. "We miss important information, an opportunity to introduce new tenants and an opportunity to remedies faults in the apartments". None of these companies follow up the causes of why tenants leave.

The respondents in both companies are essentially satisfied with their selected organization and Company A sees advantages to further develop frontline staff responsibilities; "There is a clear advantage to give more responsibilities to local staff, because they have an overall picture, and cover areas that otherwise could be missed" (quoted from a manager). According to respondents in Company $\mathrm{E}$ it is easier to coordinate work in a small housing company compared with a large 
company because of short decision-making distances and the fact that many employees know one another.

The respondents in Company A were satisfied with their model since it meant a decentralised responsibility and that it gathered important functions on the housing areas. This overall local approach helped the management to get a general picture and recognise future requirements. A negative side effect was that frontline staff sometimes worked very independently in their areas and that cooperation with employees at headquarters or in other areas were limited. However it seemed to be a clear advantage if front-line staff handled reports about disturbances because they have local knowledge. The respondents described this in a way, that front-line staffs have a natural relation to the housing area and know who lives where and the special local circumstances, etc.

Social projects were managed from the central level in both companies and with different focus depending on the need in the individual housing area. "We involve children, young people, police and all social activities are adapted according to individual housing area situation" (quoted from a manager).

An interesting phenomenon was pointed out by respondents in Company $A$ about when the frontline staff disagreed with management's directive; they instead sometimes created their own agendas and choose not to take responsibility. "It is important that we have a common attitude towards our tenants, we have experienced situations where staff had their own agendas and do not care about the management directive" (quoted from a manager). Both companies agreed that they need to increase management control and Company $E$ has increasingly started to work with clarifying procedures to reduce mistakes and increase consistency. "We work with checklists to improve quality, help staff to remember important activities and also to help tenants to make demands on us" (quoted from a manager).

Both companies used in various degrees contractors to handle more advanced apartment renovations, ongoing property maintenance and some daily maintenance activities, etc. "We introduce our contractors for the tenant, but it is quite unusual for us to check their work" (quoted from frontline staff). They seemed to rely much on tenants paying attention to ensure that the contractor's work is properly done.

\subsection{Model 3}

4.3.1 How the model worked in practice. Model 3 is a local administration model where customer service, caretaking and letting are manage together in a joint local work-team in a in-house solution. Company B and Company C used this organisational model. Company B has 21,700 apartments and 226 employees and Company $C$ has 11,600 apartments and 130 employees. The joint local work teams are organised from local offices in the housing areas.

Customer service is organised around the local level staff and tenants can contact staff by e-mail, telephone or by visiting local offices. However, both companies have kept a small central call centre to increase the service level and help tenants contact the right person. The letting process is managed from local offices with a centrally organised support function. The support function takes care of tenant control and the first steps in the tenant' selection process. Both companies have a central queue-based system. There are some exceptions where the local level has more influence and can determine the selection of a new tenant. Two examples of this are internal exchanges and when it comes to special social circumstances. The local level manages the major part of the letting process including writing tenant agreements, inspections and internal exchange.

Caretaking is managed in a similar way in both companies, but there are some basic differences. Company B created three different roles in the joint local work team. A manager operates from the local level and coordinates the work. A caretaker manages the caretaking and another person handles the letting process. In Company $C$ the local administration was similar to Company $B$ but managers were located centrally. The joint local work teams in both companies were responsible for social projects, and handling reports about different types of disturbances. This was earlier organised centrally. Staff numbers varied between different neighbourhoods and different local working groups and sometimes extra human resources were allocated to specific areas based on need. 
There are many external contractors working in the housing areas and they handle cleaning, outdoor environment, advanced faults and ongoing maintenance etc. Contractors were hired in cases when the specific task requires specialists or when the fault was very time-consuming to correct. As soon as tenants send a service request, local staff visits the dwelling to understand the magnitude of the fault. After that the local staff decide to correct the fault or order services from a specialised contractor. If the local staff decides to hire a contractor then the local staff must coordinate the contractor, control the work and authorise the invoice. Unlike Company B, Company $C$ has a centrally managed in-house organization for the outdoor environment. Company $B$ uses contractors for this activity.

The idea in Company B was from the beginning that all activities in the letting process should be managed at the local level, but the company finally chose a divided solution to increase control over the letting process. Some facts indicated that there could be situations when local staff felt pressured to give benefits to a tenant to maintain a good relationship even if this was in conflict with the company's policy. These benefits were, in some cases linked to the internal exchange and letting process. Examples of these benefits are priority of selected tenants outside the ordinary rental policy and dwelling renovation and improvements in a way that causes abnormally high transaction costs.

4.3.2 Respondents' opinions. Customer service was organised in a similar way as in model 2 and tenants contact the responsible staff directly, but they can also contact a central call centre to get help. The local offices need the right amount of resources to be available for tenants. Otherwise, situations arise when staff turns off their phones to perform their tasks. "It is important to have right capacity and have colleagues to back up in heavy working periods" (quoted from frontline-staff). The need for resources varied widely between different housing areas and in socially vulnerable neighbourhoods there was an extra need for direct contact between staff and tenants related to different languages and cultural differences.

The letting process was managed in the field, which improved the introduction of new tenants, staff knowledge and control of the dwellings. Tenants received more services and felt more welcome because of the staff's overall responsibility. The respondents in Company $C$ felt that the local letting process is practical and gives a good opportunity to introduce new tenants. There were, however, several respondents in the survey that believe potential tenants can affect operating staff in the letting process. It should be mentioned that Company B, since the survey was conducted, has tightened up tenant selection and to a higher degree use a queue-based system to avoid moral hazard problems on the local level.

Frontline staff have improved cooperation due to the joint local work team, but Company C, noticed that frontline staff in some cases work separate from other parts of the company and create their own agendas and cooperate poorly with other staff. "There is always a danger when housing areas become too isolated from other parts of the company" (quoted from a Manager).

The respondents think that it is easier to follow up various activities in the local administration and Company $\mathrm{C}$ noticed an advantage in the handling and monitoring of fault reports. "It is easier to come back to check if the work is properly done when we work close to the tenants from a local office" (quoted from frontline staff). Managers worked more closely with operational staff and staff responsibilities became clearer because of that.

To avoid varying service quality throughout the housing company, managers have put more effort into facilitating work team cooperation. Although the tenant responsibility was improved, much depends upon the group's composition and the teamwork. The housing areas have separate needs because of individual differences and it was not always easy for the central management to allocate the right level of resources. The respondents also indicated that individual responsibility in the team could be negatively affected if the group did not cooperate, and had their own agendas in the daily work. The result was that they worked poorly together. According to the local respondents this was an expression of staff's general dissatisfaction and in some cases individual personal problems. The management moved local operating staff around within the company at regular intervals to avoid some of these problems. 
Company $B$ seemed to have a problem with developing a relationship with the contractors. Company B selected special contractors in different housing areas through a central procurement process and the contractor's geographical location and price decides who gets the job instead of performance and ability to co-operate with local staff. Company $C$ also needs to improve cooperation, procurements and the monitoring-process when contractors are used. A respondent in company $C$ express it like this "The tenant makes no distinction between our own staff or our contractors and expects the same service" (quoted from a Manager).

Finally, it appears to be easier to identify needs and involve tenants and key players in social projects when resources is decentralised; "We can focus more on preventive social action instead of administrative handling of different types of disturbances"(quoted from frontline staff).

\section{Analysis}

\subsection{Introduction}

It is clear that there is a considerable lack of knowledge in this research area and that attention to service and issues related to the local organizational structure are a relatively new phenomenon in housing management. A focus on housing production dominated for many years.

Housing service is different in many ways from other types of service because there often is a long standing relationship between landlord and the tenant, as many customers/tenants do not have the same opportunity to terminate the relationship as in other businesses because housing location depends on the labour market, the wish to keep children in the same school and other social conditions that reduce mobility. This dependence is mutual because in most cases when tenants stay for many years in their dwellings it contributes to less transaction costs for the company and increases the tenant's interest to taking care of his apartment. It can also be difficult for the housing company to terminate the contract with a "bad" tenant because of legal barriers. Walker (2001), Flint (2002), Brattbakk and Hansen (2004), Lindberg and Liedholm (1998) describes this changing process where the aim is to get the housing company to work closer together with the tenants. The common theme is how to identify success factors to get tenants to fulfil their obligations. This seemed to be especially important in large socially disadvantaged housing estates. Local management with local offices is mentioned several times in housing research discussion as a solution to improve management in socially disadvantage housing areas (Lindberg, 1994a; Öresjö, 1996; Johansson, 1998; Blomè, 2006). In these areas it is especially important that local staff are visible and working to reduce anonymity in the area.

Outsourcing has become more common as a management solution and in model 1 , which is analysed below, a contractor is responsible for caretaking as an independent part of the local administration. The outsourcing requires detailed monitoring to ensure that tenants get the requested service and that agreements are enforced. Research shows a common problem in Europe in terms of rules for procurement and more knowledge is needed in this subject field (see, e.g. Lindberg, 1994a, Sirmans et al. , 1999; Saugeres and Chapman, 1999; Becker et al. , 2001).

Self-management is another management option that is not analysed in this study as an independent organization model because the studied housing companies did not to a great extent use or see that as an option. A potential moral hazard dilemma can occur when a small group of dedicated tenants, who may not represent all, get a lot of influence and power. Self-management is interesting but may perhaps be seen as an alternative in more specific cases or individual properties where company management can identify local commitment and enthusiasts among tenants and staff (see Cars et al. , 1996; Ericsson, 2002; Bengtsson et al. , 2003; Lindgren and Castell, 2008). It is probably not an efficient alternative for large-scale housing estates in socially deprived areas.

There is however no more detailed study about how to allocate decision-making powers and responsibility to the local organization for large housing estates: An interesting question is what are the alternatives and what are the advantages and disadvantages of different alternative models? 
The models described above can be discussed in more general terms from four different perspectives:

(1) the need for information about the situation in different areas;

(2) the need to motivate staff;

(3) the need to mobilise the tenants; and

(4) the need to keep a consistent policy in the company.

\subsection{Organization alternatives and consequences}

The main results of the comparisons can be summarised and systematised in the way described in Tables II-IV. Table II contains advantages and disadvantages of organising the local administration from principles of model 1 .

Model 1 is the model that differs most in comparison with model 2 and model 3 . The reason for selecting this model was the ambition to build up a pure purchasing organization and let contractors manage the local administration. This structure simplifies the administrative process and makes it easier for the staff to focus on their specific task, because customer service, the letting process and caretaking are organised as separate central or outsourced functions. As everything is carried out through the central unit there is also less moral hazard problems as there are no direct loyalties created with tenants in different areas.

However, there are some problems with model 1 that need to be noticed. To begin with, tenant contacts depend on several persons' ability to interact in an effective way, as customer services and caretaking are separated from the letting process. This might lead to information loss and long delivery times of ordered services. The Housing Company becomes dependent on the tenant's descriptions of faults to be able to deliver the correct type of service. This model creates less closeness to the tenants and the housing company may lose important local knowledge about different areas and the social conditions there. This organization should however generate less moral hazard problems in comparison with the other two presented organization models since the customer responsibility is shared between different people and levels. There might however raise problems because of difficulties in creating a clear incentive system that motivates the contractors to do the right thing. As the contractors have a rather short-term contract they might focus on fixing a problem as cheaply as possible, even if it might lead to higher long run costs. The limited work tasks in Model 1 may also lead to poorer staff motivation and less effort. Model 1 might be particularly problematic in socially disadvantage housing estates where information about the local conditions is very important. Model 1 might be more suited to more stable areas, which require less staff presence and less pro-active behaviour.

\begin{tabular}{lll}
\hline & Advantage & Disadvantage \\
\hline Model 1 & Simplified administrative process & Information loss \\
& Less moral hazard & Less tenant closeness \\
& Less housing area knowledge \\
\hline
\end{tabular}

Table II. Advantages and disadvantages of model 1

\begin{tabular}{lll}
\hline & Advantage & Disadvantage \\
\hline Model 2 & Local approach & Information loss \\
& Less moral hazard & Less tenant closeness \\
& Suitable in socially deprived areas & $\begin{array}{l}\text { Less housing area knowledge (in the } \\
\text { letting process) }\end{array}$ \\
\hline
\end{tabular}

Table III. Advantages and disadvantages of model 2 


\begin{tabular}{lll}
\hline & Advantage & Disadvantage \\
\hline Model 3 & Total local responsibility & Isolated local working teams \\
& Staff collaboration & Increased risk of moral hazard \\
& Clear responsibilities & \\
& Suitable in socially deprived areas & \\
\hline
\end{tabular}

Table IV. Advantages and disadvantages of model 3

Table III contains advantages and disadvantages of organizing the local administration from the principles of Model 2.

Model 2 has a similar problem as model 1 with possible loss of information between central staff and local housing area staff, especially during the letting process and information to new tenants. These information losses may adversely affect tenants. One way to counteract these side effects is to increase information exchange and have frequent contacts between staff groups. A clear advantage in model 2 is less risk that staff are affected by different types of pressures from tenant, as the letting process is not their responsibility. It is obvious that situations when tenants put pressure on staff to do extra services beyond the company's policy are difficult to control in a decentralised organisation. From a moral hazard perspective it could then be an advantage to manage the letting process at the central level and to separate responsibility between the different levels and different types of staff. Model 2 has more potential to work well in socially disadvantage housing estates compared to model 1 , because both customer services and caretaking are carried out at the local level and that the local housing office has a broad responsibility, which means that all ordinary contacts with the current tenants go through this local team with an office in the area. The staff can also be reached on mobile phones all time during the day by the tenants. Table IV contains advantages and disadvantages of organizing the local administration from principles of Model 3.

Model 3 should be recognised as an interesting model for municipal housing companies with a large proportion of their estates in socially disadvantageous areas. This model appears to make it easier for the housing company to understand the needs in different areas as there are strong and integrated work teams located in the area. Model 3 can in particular contribute to bringing together and coordinating local resources. Moral hazard problems can however arise when local staff have more power and identify more with the area than with the company's objectives. These problems in model 3 can be limited by using comprehensive working rules and operating routines, e.g. in relation to letting policy. Increased control by the company and rotating staff might also reduce these problems.

These arguments indicate that different models might be used in the same organization, depending on the specific characteristics of the areas. There may be advantages to having a flexible organization and adapting organizational structures and activities to the specific circumstances. Regardless of the type of organizational model, the housing company can also choose between a larger and smaller role for different types of external contractors, but the general pattern should be that if more information is needed and that this information should be shared (as in model 3 ) it limits the role of external contracts, except for more special repairs and major renovations.

\section{Conclusion}

The models described and analysed have been discussed from four different perspectives:

(1) the need for information about the situation in different areas;

(2) the need to motivate staff;

(3) the need to mobilise the tenants; and

(4) the need to keep a consistent policy in the company. 
There seems to be fundamental conflicts between these goals and that there is a need to balance the different goals in relation to each other and that this balance will be different in different types of housing estates.

Model 1, where more functions are centralised and caretaking, in the extreme case, is run by external contractors without local offices, it does presuppose that the company does need much more information about the local situation and does not need to mobilise tenants. It is therefore suitable in areas with few problems and stable tenants. This is also typically the case in the companies that use Mode1 1 . It is however also important in this case that information from the tenants, can be managed with, e.g. yearly questionnaires measuring customer satisfaction.

Model 2 and model 3, where more functions are decentralised are likely to work better in socially disadvantaged large housing estates than model 1 . In these cases, a local presence is important and the company continuously needs detailed information about the social situation in the area and if there are tendencies for certain problems, e.g. vandalism, tends to increase and why.

The advantage of Model 3 is that, especially for the introduction of new tenants, new tenants and local staff can build up a relationship from the beginning. The main problem with especially model 3 is the moral hazard problem. The local staff may create their own agenda, get pressured by certain tenants and create informal alliances with certain groups of tenants. All this also means that much information will be kept in the local group and not transferred to the company managers. We can see that one of the companies using Model 3 recently has strengthened the central control of especially the letting process and also is discussing rotating staff between different areas.

Over the past 20 years the Swedish housing market has changed in several ways, the most important is that subsidies have been reduced and that the tenant group is more heterogeneous due to a large number of refugees etc. The need to increase efficiency in a difficult situation has created new challenges for housing management. The different organizational models presented in this study are all examples of the housing companies' efforts to adapt to the new situations.

Other European countries have had a similar refugee situation as Sweden and many new arrivals are concentrated to large housing estates neighbourhoods. Although housing policy is different between countries it would be of interest to investigate differences and similarities in how the local housing administration is organised and if the Swedish experience described in this paper can be generalised.

One thing that falls outside the scope of this study but still is of current interest is how the economic profitability differs between different organizational models in relation to tenants' perceived service quality. Since outsourcing is frequently used in real estate management, there is also a need for more detailed studies on how contractors affect efficiency and tenants perceived service quality.

\section{References}

Andersson, R., Molina, I., Öresjö, E., Petersson, L. and Siwertsson, C. (2003), Large Housing Estates in Sweden. Overview of Developments and Problems in Jönköping and Stockholm, Utrecht University, Utrecht.

Andersson, R., Öresjö, E., Petersson, L., Holmqvist, E., Siwertsson, C. and Solid, D. (2005), Large Housing Estates in Stockholm and Jönköping, Sweden. Opinion of Residents on Recent Development, Utrecht University, Utrecht.

Becker, F., Dluhy, M. and Tropinka, J. (2001), "Choosing the rowers: are private managers of public housing more successful than public managers?", American Review of Public Administration, Vol. 31 No. 2, pp. 181-200.

Bengtsson, B., Berger, T., Fransson, N., Lind, J-E. and Modh, B. (2003), Lokal kontroll och kollektivt handlande: En utvärdering av självförvaltning $i$ Bostads $A B$ Poseidon i Göteborg, Uppsala universitet, Uppsala. 
Blomè, G. (2006), "Kundnära organisation och serviceutveckling i bostadsföretag", Kungliga tekniska högskolan.

Borg, L. and Lind, H. (2007), De allmännyttiga bostadsföretagens framtid, Divison of Building and Real Estate Economics, Royal Institute of Technology, Stockholm.

Brattbakk, I. and Hansen, T. (2004), "Post-war large housing estates in Norway - well kept residential areas still complexities?", Journal of Housing and Built Environment, Vol. 19 No. 3, pp. 311-32.

Cars, G., Olsson, K. and Snickars, F. (1996), Kulturmiljö på spel; En studie av strategier att bevara och utveckla den byggda miljöns kulturvärden, Riksantikvarieämbetet, Stockholm.

Deakin, M. (1998), "The development of computer based information systems for local authority property management", Property Management, Vol. 16 No. 2, pp. 61-81.

Ericsson, U. (2002), Gårdar och livsstil I förändring; enkäter med innerstadsbor $i$ agenda 21projektet "Grönskande levande gårdar" före och efter förnyelsen, Slutrapport, Stockholm.

Flint, J. (2002), "Social housing agencies and the governance of anti-social behaviour", Housing Studies, Vol. 41 No. 1, pp. 519-637.

Franklin, J. (2000), "Demands, expectation and responses. The shaping of housing management", Housing Studies, Vol. 15 No. 6, pp. 907-27.

Gummesson, E. (2004), Fallstudiebaserad forskning. Kunskapande metoder inom samhällsvetenskapen, Studentlitteratur, Lund.

Hickman, P. and Reid, B. (2002), "Are housing complexities becoming learning complexities? Some lessons from the management of tenant participation", Housing Studies, Vol. 17 No. 6, pp. 895-918.

Högberg, A-L. and Högberg, E. (2000), Kunddriven fastighetsförvaltning, Daleke grafiska, Malmö.

Högberg, L., Lind, H. and Grange, C. (2010), "Incentives for improving energy efficiency when renovating large-scale housing estates: a case study of the Swedish million homes programme", Sustainability, Vol. 1 No. 4, pp. 1349-65.

Johansson, U. (1992), Företagsanpassad fastighetsskötareutbildning utvärdering av ett utbildningsoch utvecklingsprojekt i Ludvika, SABO.

Johansson, U. (1994), Föreställningar om ansvar i bostadsföretag, Stockholms byggforskningsråd.

Johansson, U. (1998), Om ansvar. Ansvarsföreställningar och deras betydelse för den organisatoriska verkligheten, Lunds Universitet, Lunds.

Lennartsson, H., Lind, J. and Soidre-Brink, T. (1992), Från spröt till grund. Hyresgästernas lokala organisering och boendeinflytande, Göteborgs Universitet, Göteborgs.

Liedholm, M. (1991), Boinflytande och deltagande som fenomen och process, Lund University, Lund.

Lindberg, G. (1994a), "SABO företagens organisationsutveckling. Rapport från forskaregruppen Boende och bebyggelse", Lunds Universitet, Lunds.

Lindberg, G. (1994b), "Nygammal portvakt. Ett lyft i allmännyttan", Tidskriften Byggforskning, Vol. 1.

Lindberg, G. and Liedholm, M. (1998), Kommunikation och integration i boendet, Lunds Universitet, Lund.

Lindgren, T. and Castell, P. (2008), "Open space management in residential areas - how it is organized and why", International journal of Strategic Property Management, Vol. 12 No. 3, pp. 141-60.

Mintzberg, H. (1979), The Structuring of Organizations. A Synthesis of the Research, Prentice-Hall, Englewood Cliffs, NJ.

Öresjö, E. (1996), Att vända utvecklingen. Kommenterad genomgång av aktuell forskning om segregation i boendet, SABO. 
Öresjö, E., Andersson, R., Holmqvist, E., Petersson, L. and Siwertsson, C. (2004), Large Housing Estates in Sweden. Policies and Practices, Ulrecht University, Ulrecht.

Owen, S. (2002), "From village design statements to parish plans. Some pointers towards community diction making on the planning system in England", Planning Practise and Research, Vol. 17 No. 1, pp. 81-9.

Power, A. and Tunstall, R. (1995), Swimming Against the Tide: Progress of Polarisation on 20 Unpopular Estates, Joseph Rowntree Foundation, York.

Ramberg, R. (2000), Välfärdsbygge 1850-2000, SABO, Stockholm.

Robinsson, D. (2006), "Transforming social housing: taking stock of new complexities", Housing Studies, Vol. 21 No. 2, pp. 157-70.

Saugeres, L. and Chapman, D. (1999), "The social construction of housing management discourse: objectivity, rationality and everyday practice", Housing, Theory and Society, Vol. 16 No. 3, pp. 93-105.

Sirmans, G., Sirmans, C. and Turnbull, G. (1999), "Prices, incentives and choise of management form", Regional Science and Urban Economics, Vol. 29 No. 2, pp. 173-95.

Statistics Sweden (2009), available at: www.scb.se.

Turkington, R. (1995), "Models or muddle? Intervention on large housing estates: privatisation and the British experience", Lund University, Lund.

Van Kempen, R., Murie, A., Knorr-Siedow, T. and Tosics, I. (2006), "Regenerating large housing estates in Europe. A guide to better practice", Utrecht University, Utrecht.

Van Mosel, J.H. (2008), "The purchasing of maintenance service delivery in the Dutch social housing sector. Optimising commodity strategies for delivering maintenance services to tenants", Delfts University of Technology, Delfts.

Walker, M. (2001), "How to abolish public housing: implications and lessons from public management reform", Housing Studies, Vol. 16 No. 5, pp. 675-96.

\section{Further Reading}

Alfredsson, B. and Cars, G. (1996), De boende som medarbetare i självförvaltningen i Holma, SABO Utveckling, Enskede.

\section{Illustration}

Figure 1: Only caretaking (c) at the local level

Figure 2: Costumer service (a) and caretaking (c) at the local level

Figure 3: Costumer service (a), letting (b) and caretaking (c) are all carried out at the local level

Table I: Empirical methods used

Table II: Advantages and disadvantages of model 1

Table III: Advantages and disadvantages of model 2

Table IV: Advantages and disadvantages of model 3 